Urban Politics in

Victorian England 
Derek Fraser's other books for Macmillan include:

The Evolution of the British Welfare State (1973) and

The New Poor Law in the Nineteenth Century of which he

is the editor. 


\section{Urban Politics in Victorian England}

The structure of politics

in Victorian cities

\section{Derek Fraser}




\section{Copyright (C) Leicester University Press 1976}

All rights reserved. No part of this publication may be reproduced, stored in a retrieval system, or transmitted, in any form or by any means, electronic, mechanical, photocopying, recording, or otherwise, without the prior permission of the Leicester University Press.

First published in 1976 by Leicester University Press

First published in paperback 1979 by

THE MACMILLAN PRESS LTD

London and Basingstoke

Associated companies in Delhi Dublin

Hong Kong Johannesburg Lagos Melbourne

New York Singapore and Tokyo

Reproduced photolitho in Great Britain

by J. W. Arrowsmith Ltd., Bristol.

British Library Cataloguing in Publication Data

Fraser, Derek

Urban politics in Victorian England.

1. Metropolitan government - England - History

- 19th century

2. Great Britain - Politics and government -

$1837-1901$

I. Title

$320.9^{\prime} 42^{\prime} 081$

JS3065

ISBN 978-0-333-27885-7 ISBN 978-1-349-05137-3 (eBook)

DOI 10.1007/978-1-349-05137-3

This book is sold subject to the standard conditions of the Net Book Agreement.

The paperback edition of this book is sold subject to the condition that it shall not, by way of trade or otherwise, be lent, resold, hired out, or otherwise circulated without the publisher's prior consent, in any form of binding or cover other than that in which it is published and without a similar condition including this condition being imposed on the subsequent purchaser. 


\section{Contents}

Preface

List of tables and maps

page 7

Introduction: the structure of politics in Victorian cities

Part One Parochial and Township Administration

1 The vestry as a political institution $\mathbf{2 5}$

2 The churchwardens 31

3 The Poor Law 55

4 The improvement commissions 91

$\begin{array}{lll}5 & \text { The highway surveyors } & 103\end{array}$

Part Two Municipal Govermment

6 Council politics $\quad 115$

7 The politics of improvement 154

Part Three Parliamentary Elections

8 Elections and society 178

9 Electoral analysis $\quad \mathbf{2 1 4}$

Part Four Political Agitation

10 The free trade movement 237

11 Suffrage reform $\quad 252$

12 Church and education 265

$\begin{array}{ll}\text { Conclusion: urban politics in modern England } & \mathbf{2 7 9}\end{array}$

$\begin{array}{ll}\text { Notes } & \mathbf{2 8 6}\end{array}$

Select time chart 1812-80

$\begin{array}{ll}\text { Index } & \mathbf{3 1 7}\end{array}$ 
To Jim Dyos 


\section{Preface}

This book is the product of about a dozen years' research, some of which was not originally intended for the present purpose. My initial research was in the field of newspaper history and, though dimly aware of it at the time, I struck a vein of political consciousness which informed opinion across a wide range of issues. Later when I began my study of Leeds politics, I was able to explore the institutional framework of this intense urban political sensibility. Having completed a doctorate, I extended the chronological range of the Leeds material and ventured further afield to other cities in a search for evidence for a more general model of urban history in the nineteenth century. The present book is the fruit of that search and it has benefited much from the help of many whose aid I am delighted to acknowledge.

I am indebted to the School of History at Leeds which not only gave me my undergraduate training but also provided the opportunities to pursue two postgraduate research projects. I owe much to the early guidance of Asa Briggs and Donald Read, who were my initial mentors. At a later stage Arthur Taylor and Gordon Forster were sympathetic and helpful supervisors. Over the years many scholars have been generous in the provision of advice and guidance. I am pleased to record thanks to Michael Rose, Norman McCord, Maurice Beresford, Peter Hennock, Bob Morris, Vic Gatrell, and Reg Ward. Many others with whom I had less frequent contact, and countless librarians, also deserve thanks. Jack Reynolds, my colleague at Bradford, has provided much stimulating conversation and has been characteristically generous in sharing with me his unrivalled knowledge of Bradford history. Two of our research students, David Ashforth and Adrian Elliott, gave me interesting leads which flowed from their work and I thank them both. I have learned a great deal, especially about source material, from the many theses $I$ have consulted and I am grateful to their authors for permission to cite their work. I am particularly indebted to Tom Nossiter, with whom I have had some healthy disagreements, but who also supplied valuable statistical data with the appropriate instruction. The dedication records my respectful thanks to one who has encouraged and supported my work over a number of years.

Nearer home Carol Baxendale made an excellent job of typing up a complex manuscript and Jim Morgan demonstrated his friendship by reading the book at both typescript and proof stage. I thank him for his many useful suggestions. At home my wife and family bore well the mounting piles of photocopies which littered every room. It has been a pleasure to deal with Leicester University Press, for whom Peter Boulton has been unfailingly courteous and helpful. I trust that those who, by their aid, have demonstrated the existence of a community of scholars will consider that I have used their counsel wisely. Responsibility for errors and shortcomings remains mine alone.

DEREK FRASER 


\section{Tables and maps}

Table 1. Churchwardens' poll, Manchester 1833 page 38

2. Political composition of Leeds board of guardians, 1844-68 58

3. Results of first municipal elections $\quad 124$

4. Political composition of Leeds council, 1835-80 125

5. Council attendance, Leeds 1836-41 128

6. Social composition of Leeds town council, 1836-52 129

7. Social composition of municipal candidates, Leeds 1841-70 131

8. Estimated numbers of municipal voters, Leeds 1872-4 133

9. Social composition of Leeds town council, 1874-5 133

10. Political composition of Liverpool town council, 1835-67 137

11. Political composition of Nottingham town council, 1835-40 143

12. Contested municipal elections, 1835-67 146

13. Percentage of non-contested municipal elections, Leeds 18351880

14. Wealth and municipal voting in Leeds
15. Percentage of non-contested municipal elections, Liverpool 1835-67

16. Wealth and municipal voting in Liverpool, 1835-67 221

17. Proportion of electorate deemed to be working class, $1865 \quad 223$

18. Percentage Conservative share of poll in large two-member constituencies, 1832-80

19. Swing in English two-member boroughs, 1832-80

20. Percentage Liberal support in designated social groups
21. Occupation and voting, Leeds $1832-41$

22. Percentage of each party falling into occupational groups, Leeds council, 1841

23. Percentage Conservative share of poll in Leeds wards, 1832-68 232

24. Rank order correlation between parliamentary voting, municipal voting, and wealth, in Leeds wards

Map 1. The townships and wards of Leeds, with accompanying diagram showing the percentage share of seats won by Conservatives in Leeds municipal elections, $1835-80$, by wards

2. The townships and wards of Liverpool, with accompanying diagram showing the percentage share of seats won by Conservatives in Liverpool municipal elections, 1835-67, by wards

Front Cover: The high point of the 'Leeds new move' on suffrage reform was the splendid festival held in Marshall's new mill in January 1841. Ominously, the Chartists passed a universal suffrage amendment and O'Connor dubbed the gathering the Fox and Goose Club. The Northern Star published a cartoon, from which this is a detail, depicting the working-class audience as geese among the Egyptian pillars of Marshall's mill, and the middle-class leaders as foxes ready to feast upon an easy prey.

By courtesy of the Trustees of the British Museum. 